\title{
Paratuberculosis: Diagnostic Methods and their Constraints
}

\author{
Maroudam V, Mohana Subramanian B*, Praveen Kumar P and Dhinakar Raj G \\ Translational Research Platform for Veterinary Biologicals, A DBT-TANUVAS Partnership Initiative, Madharavaram Milk Colony-600 051, Chennai.
}

*Corresponding author: Mohana Subramanian, Scientist, Translational Research Platform for Veterinary Biologicals, A DBT-TANUVAS partnership initiative, Madharavaram Milk Colony, Chennai-51, Tel: 44-25551586; E-mail: bmohan@tanuvas.org.in

Rec date: Jun 22, 2015; Acc date: Sep 11, 2015; Pub date: Sep 13, 2015

Copyright: (c) 2015 Maroudam V, et al. This is an open-access article distributed under the terms of the Creative Commons Attribution License, which permits unrestricted use, distribution, and reproduction in any medium, provided the original author and source are credited.

\begin{abstract}
Paratuberculosis (Johne's disease) is a chronic intestinal disease of ruminants and the disease is caused by Mycobacterium avium subspecies paratuberculosis (MAP). The disease has a prolonged pre-patent period and the clinical symptoms of the disease are apparent only during the later stages of the disease. However, the infected animal can shed the organism much before the clinical disease with the risk of spreading the disease to other susceptible animals. The disease manifestation is in four stages with each of these stages requiring a different diagnostic method. During the early stages of the disease Cell mediated immune response (CMI) is higher, and shedding of the organism and serum antibody response is absent or minimized. Delayed type hypersensitivity (DTH) response upon injection of Johnin purified protein derivative (Johnin PPD) in the skin of the animal and interferon gamma release assay (IGRA) is the common CMI based tests for the diagnosis of paratuberculosis. As the disease progress, CMI response reduces and humoral response predominates with progressively increased shedding of the organism. ELISA based tests are commercially available to detect the MAP specific antibodies in serum or milk, and nucleic acid detection methods are used to identify the organism. However, all these CMI and humoral antibody based tests have advantages and disadvantages. It is essential to apply a combination of these tests to detect or rule out the disease in farms of endemic countries.
\end{abstract}

\section{Keywords: Paratuberculosis, MAP; ELISA; IFN- $\gamma$}

\section{Introduction}

Johne's disease (JD) or paratuberculosis is a chronic, progressive and incurable intestinal disease of domestic and wild ruminants. The disease is caused by Mycobacterium avium subspecies paratuberculosis (MAP) with severe economic losses in animal husbandry. MAP causes a severe reduction in milk yield and culling of infected animals is advised to prevent spread of the disease $[1,2]$. Calves under one year are more susceptible for the disease and ingestion of feed contaminated with infected materials is the primary cause of infection $[3,4]$. Clinically positive cattle shed the organism in feces [5,6] and milk [7] which results in greater risk for animal as well as human exposure. The histopathological and clinical similarities between JD and Crohn's disease $(C D)$ in humans had created the apprehension that MAP might be a zoonotic organism [8].

Young animals get the infection through a contaminated birthing environment, infected colostrum/milk and rarely in the uterus. Calves rarely show clinical signs during the initial two years of age, whereas clinical signs start appearing in 2 to 6 years of age. Gross pathological lesions are usually absent in the subclinical stage of infection [9]. Antibody response is not generally sufficient to confer protection against the disease. However, MAP antibodies in milk or serum samples during the pre-clinical and clinical stages aid in disease diagnosis. Development of CMI response through the IFN- $\gamma$ producing T-cells (Th1 subset) are critical for the host defense against intracellular MAP in restricting the replication of the bacteria. The CMI response is developed very early in the MAP infection and therefore, CMI based diagnostic tests are used for early diagnosis of JD [10]. Diagnosis of MAP is a challenge due to the chronic nature and the occurrence of four stages of disease viz, stages I: silent infection; stage II: unapparent carrier animals; stage III: clinical disease; stage IV: advanced clinical disease [11]. Diagnosis in stage III and stage IV is not very complicated as the infected animal sheds the organism, shows clinical signs and the animals seroconvert. However, diagnosis is complicated in stages I and II as there are no clinical signs and low shedding of MAP. Thus, this review focuses on the clinical significance of MAP infection and diagnostic strategies using novel immune and molecular assays.

\section{Etiology}

MAP is a gram positive, acid fast, non-motile, the facultative intracellular pathogenic bacterium which was first isolated in 1895 by Dr. Heinrich Albert Johne and hence called "Johne's" disease. Mycobacteria do not seem to fit the gram-positive group (because they generally do not retain the crystal violet stain well) and based on their characteristic cell wall they are classified as acid-fast bacterium. The cell wall is thicker, hydrophobic, waxy and rich in mycolic acids/ mycolates. The hydrophobic mycolate layer and a peptidoglycan layer were held together by a polysaccharide, arabinogalactan which contributes to the hardness of the cell wall. Mycobacteria cells are straight or slightly curved rods with $0.2-0.6 \mu \mathrm{m}$ width and $1.0-10 \mu \mathrm{m}$ length. MAP requires exogenous supplementation with ferric mycobactin $J$ for growth and adapts readily to grow on media containing ammonia or amino acids and glycerol as nitrogen and carbon sources, respectively. Optimum growth temperature of the organism varies extensively and it ranges from $25^{\circ} \mathrm{C}$ to over $50^{\circ} \mathrm{C}$. Although the etiology of paratuberculosis has been known for decades, the appropriate criteria for subtyping MAP strains is a challenging task. However, the information on MAP sub-types are started appearing recently [12]. 
Page 2 of 9

\section{Economic impact}

Economic consequences of JD have been investigated, particularly in dairy cattle herds from various countries [13-15]. Researchers have used various methods for estimation of economic losses caused by JD and comparing findings is difficult. Economic losses caused by JD vary among regions and farms [16]. The reported losses varied with the production and management system, immunological status of the herd and presumably with the method of estimation [13]. Calculation of economic losses to the dairy industry due to subclinical MAP infection is another challenge. This is due to the difficulty in identifying subclinical carriers and assessing the impact of infection on the productivity of these animals [15]. Determining indirect costs and productivity losses of clinical and subclinical form of the disease is also a tough task [17]. Economic losses by JD are due to premature culling, reduced milk production and loss of body weight in beef cattle [18]. When dairy cows were tested for JD using the milk ELISA test, test positive cattle had $3 \mathrm{~kg}$ less milks on test day than their comparable test negative herd mates indicating a milk production loss in subclinical cows $[19,20]$.

\section{Zoonotic concerns}

Ruminant paratuberculosis is pathologically similar to human inflammatory bowel disease (IBD) [21] which includes three pathological forms: Crohn's disease (CD), ulcerative colitis (UC) and indeterminate colitis or unclassified IBD [22]. Currently, no widely accepted consensus has been reached about the etiologic role of MAP in human cases of regional enteritis. Isolation of cell wall deficient forms of MAP from Crohn's patients [23] microbiologically supported the 70 year old Dalziel's notion that human and ruminant intestinal regional granulomatous inflammatory diseases were similar entities. Since then, there have been several reports towards the same direction [24-26]. Crohn's disease in humans is similar to Johne's disease in animals, both clinically (Table 1) and also pathologically. However, it is unclear whether the disease is a consequence of MAP infection. Evidence of MAP was found more often in people with CD. It is unknown whether CD patients developed their disease first and then acquired the MAP infection or MAP actually contributed to their disease. CD patients also had antibodies to MAP in their blood more often than controls. Humans are likely been exposed to this organism through the food supply [27]. However, clear cut evidences of cattle to be a source of MAP for the people has not yet been established [28]. Recent studies have shown that MAP present in milk can survive pasteurization and these results have raised human health concerns due to the widespread nature of MAP in modern dairy herds. The zoonotic concern is much to be apprehended since MAP is heat resistant and is capable of hiding inside white blood cells. It has also been reported to survive chlorination in municipal water supplies which might lead to the spread of infection to the humans $[29,30]$. Currently, the human medical community tends to ignore or be skeptical on an alleged role of MAP in human intestinal inflammatory disease [31,32]. However, the epidemiologist and veterinary communities appear to be more cautious as they have to balance the public health duties related to zoonosis prevention and to avoid livestock industry damages caused by the unjustified food safety crisis [33]. MAP was detected in the raw and pasteurized milk and milk products from various countries [28]. Regarding food safety, it should also be guaranteed that milk and dairy products are free of MAP. These measures could significantly decrease the zoonotic potential of $\mathrm{CD}$ in the people at risk.

\begin{tabular}{|l|l|l|}
\hline Clinical feature & Crohn's disease & Paratuberculosis \\
\hline Diarrhea & Yes & Yes \\
\hline Intermittent diarrhea & Yes & Yes \\
\hline Abdominal pain & Yes & $*$ \\
\hline Weight loss & Yes & Yes \\
\hline obstruction & Yes & No \\
\hline Lleac region mass & Yes & No \\
\hline Blood in stool & Yes & Rare \\
\hline Vomiting & Yes & No* \\
\hline Quiescent periods & Yes & Yes \\
\hline
\end{tabular}

Table 1: Clinical similarity between CD and Johne's disease [24]. * Domestic animals generally fail to display the chronic pain. ${ }^{* *}$ Vomiting regurgitation is uncommon in ruminants, although they eructate (move ingesta from their mouth for repeated mastication, commonly called chewing their cud).

\section{Transmission and host range}

The main reservoir for MAP in nature is infected animals and an infected ruminant excretes MAP in its feces. The severity and rate of progression of the disease are dependent on the quantity of organisms and the age of the animal during exposure. Only a small dose of organisms may be required to establish infection in a newborn calf. Prenatal infection of calves is acquired in-utero [34] and postnatal infection of calves is through colostrum/milk or ingestion of the organism while suckling the teats with fecal contamination. Fecal contamination of the environment is the most common source of infection in adult cattle [3]. The primary route of infection in cattle population occurs by fecal oral ingestion of $M A P$ from contaminated feed, water and soil [35]. Had identified that the prevalence of paratuberculosis is higher in bulls than cows. Cows can be infected with MAP organism through semen from shedder bull or contaminated semen [36]. Considering the natural history of MAP and good manufacturing practices, the raw milk from MAP-infected dairy herds, the cuts of beef from MAP-infected beef cattle and the domestic water from surface sources which are vulnerable to runoff from MAPinfected farms can potentially result in human exposure. Paratuberculosis is predominant in cattle and sheep and also reported on hosts other than domestic animals listed in Table 2 [37].

\begin{tabular}{|l|l|}
\hline Species & Country \\
\hline Alpaca (Lama pacos) & Australia \\
\hline Antelope kudu (Tragelaphusstrepsiceros) & Czech Republic \\
\hline Axis deer (Axis axis) & USA \\
\hline Bactrian camel (Camelusbacterianus) & USA \\
\hline Bighorn sheep (Oviscanadensis) & USA \\
\hline Capricorn (Capra cylindrycornis) & Czech Republic \\
\hline European red deer (Cervuselaphus) & $\begin{array}{l}\text { Czech Republic, Scotland, } \\
\text { Ireland and New Zealand }\end{array}$ \\
\hline
\end{tabular}




\begin{tabular}{|l|l|}
\hline Fox (Vulpesvulpes) & UK \\
\hline Jimelatopi(Damaliscuslunatusjimela) & USA \\
\hline Moose (Alcesalces) & USA \\
\hline Pudu (Pudupudu) & Belgium \\
\hline Pygmy ass (Equusasinus form. dom.) & The Netherlands \\
\hline Rabbit (Oryctolaguscuniculus) & UK \\
\hline Rocky Mountain goat (Oreamnosamericanus) & USA \\
\hline Roe deer (Capreoluscapreolus) & Czech Republic \\
\hline Sika deer (Cervusnippon) & USA \\
\hline Stoat (Mustelaerminea) & UK \\
\hline Stumptail macaques (Macacaarctoides) & USA \\
\hline Tule elk (Cervuselaphusnannodes) & USA \\
\hline White-tailed deer (Odocoileusvirginianus) & USA \\
\hline
\end{tabular}

Table 2: Hosts of paratuberculosis other than domestic ruminants [37].

\section{Pathogenesis and clinical signs of the disease}

Clinical signs of JD are rarely evident until two or more years after the initial infection, which usually occurs shortly after birth. Most of the clinical cases are seen in 2 to 6 year old animals. Clinical signs usually appear in young adulthood, but the disease can occur in animals of any age. Within a few weeks of infection, a phase of multiplication of MAP begins in the walls of the small intestine. Depending on the resistance of the individual animal, this infection is eliminated or the animal remains infected as a healthy carrier. A later phase of the multiplication of the organisms in a proportion of carrier animals leads to the extension of lesions, interference with gut metabolism and clinical signs of disease. The initial signs of JD can be subtle and may be limited to weight loss, decreased milk production, or roughening of the hair coat. The clinical signs are similar in other ruminants. In sheep and goats, the wool or hair is often damaged and easily shed; diarrhea is uncommon. In deer, paratuberculosis can progress rapidly. Intestinal disease has also been reported in rabbits and nonhuman primates. The diarrhea in cattle is usually thick, without blood, mucus, or epithelial debris. Diarrhea is less common in small ruminants. Several weeks after the onset of diarrhea, a soft swelling may occur under the jaw which is known as "bottle jaw" or inter mandibular edema. This symptom is due to protein loss from the bloodstream into the digestive tract. Early lesions occur in the walls of the small intestine and the draining mesenteric lymph nodes, and infection is confined to these sites at this stage. As the disease progresses, gross lesions occur in the ileum, jejunum, terminal small intestine, caecum and colon, and in the mesenteric lymph nodes. MAP is present in the lesions alone and terminally, throughout the body. The intestinal lesions are responsible for the protein leak and a protein malabsorption syndrome, which lead to muscle wasting. Paratuberculosis is progressive; affected animals become increasingly emaciated and usually die as the result of dehydration and severe cachexia. Cattle with subclinical infection frequently have problems of infertility and mastitis [38-40]. The bacteria are carried by macrophages to other organs, particularly the uterus, the fetus, the mammary gland, the testes and semen of bulls. MAP was distributed in various organs, tissues and secretion of infected animals. Main features of the four major stages of the paratuberculosis pathogenesis are detailed in Table 3.

\begin{tabular}{|c|c|c|c|c|}
\hline Features & I: Silent infection & II: Inapparent carrier & III: Clinical disease & $\begin{array}{l}\text { IV: Advanced clinical } \\
\text { disease }\end{array}$ \\
\hline Replication of MAP & $\begin{array}{l}\text { Slow proliferation in jejunal and } \\
\text { ileal mucosa and spread to } \\
\text { regional lymph nodes }\end{array}$ & $\begin{array}{l}\text { Continued replication in infected } \\
\text { tissues }\end{array}$ & $\begin{array}{l}\text { Infection becoming disseminated. } \\
\text { MAP present in extra intestinal sites }\end{array}$ & $\begin{array}{l}\text { Widespread proliferation } \\
\text { and replication of MAP }\end{array}$ \\
\hline Shedding & $\begin{array}{l}\text { Intermittent shedding of the } \\
\text { organism at low levels in feces }\end{array}$ & $\begin{array}{l}\text { Most animals shed the organism } \\
\text { in feces and possibly in milk }\end{array}$ & $\begin{array}{l}\text { Shed increasing numbers of MAP in } \\
\text { feces and milk }\end{array}$ & $\begin{array}{l}\text { Shedding large numbers of } \\
\text { MAP in feces and milk - } \\
>1000 \text { cfu/g feces=super } \\
\text { shedders }\end{array}$ \\
\hline CMI response & $\begin{array}{l}\text { Th1 CMI responses initiated to } \\
\text { control infection }\end{array}$ & $\begin{array}{l}\text { Increasing CMI response. } \\
\text { Gradual switch from Th1 to Th2 }\end{array}$ & May be detectable & Possibly energy \\
\hline Humoral immune response & none & $\begin{array}{l}\text { Increasing antibody response } \\
\text { IgG2,lgG1 }\end{array}$ & $\begin{array}{l}\text { Predominantly strong } \text { antibody } \\
\text { response }\end{array}$ & $\begin{array}{l}\text { Predominantly strong } \\
\text { antibody response }\end{array}$ \\
\hline Clinical signs & None & None & Gradual weight loss and diarrhea & $\begin{array}{l}\text { Emaciation, brofuse } \\
\begin{array}{l}\text { diarrhea, bottle jaw, } \\
\text { cachexia }\end{array}\end{array}$ \\
\hline Histopathological changes & None detected & $\begin{array}{l}\text { Detectable granulomas if multiple } \\
\text { tissues examined }\end{array}$ & $\begin{array}{l}\text { Abundance of lymphocytes, epithelioid } \\
\text { macrophages and giant cells in } \\
\text { infected tissues, blunted villi }\end{array}$ & $\begin{array}{lr}\text { Abundance } & \text { of } \\
\text { lymphocytes, } & \text { epithelioid } \\
\text { macrophages } & \end{array}$ \\
\hline
\end{tabular}

Table 3: Different stages of the paratuberculosis [70].

\section{Diagnosis/current testing options}

Most of the animals shed the bacteria long before the appearance of clinical signs [41] and these shedders spread the infection to other animals by contaminating the environment. Thus, it is important to diagnose the disease long before the clinical signs appear. However, the major problem in control and possible eradication of paratuberculosis is the poor ability to identify the animals that are infected with MAP 
bacteria in early stages of the infection. This is because of the prolonged prepatent period of infection, the predominantly subclinical nature of the disease and lack of tests for accurate and early detection of sub-clinically infected animals [42]. There are many commercially available tests for paratuberculosis with their own advantages, disadvantages, and appropriate applications. Several types of MAP diagnostic tests are available such as agent detection from feces and tissues, MAP-specific antibody detection, detecting MAP-specific CMI responses and MAP specific nucleic acid detection.

MAP culture is considered to be the most reliable gold standard method. However, the bacterial growth is slow with test results being available only after months of incubation and sampling of multiple tissues may be required to establish the infection status of an animal [43]. However, it is also widely recognized that fecal culture results would severely underestimate true infection status and the fecal cultures have a high level of test failures due to the contaminating bacteria in the feces and irregular shedding [44]. Pooling of fecal samples (e.g. Five samples per pool) can establish a herd's infection status at a lower cost, despite some reduction in test sensitivity. Genetic probes to MAP DNA, such as IS900, can be used in conjunction with culture or directly on fecal samples. Acid-fast (Ziehl-Neelsen) staining of fecal smears is also used as an alternative diagnostic method with the same limitation of very low sensitivity. Thus the detection of MAP in feces or fecal cultures is possible only in the shedder animals with limited sensitivity.

Culture and histopathology on multiple tissue samples during necropsy is used as a definitive diagnosis. Ziehl-Neelsen staining of tissue samples usually reveals abundant acid-fast bacteria (Mycobacteria) in lesions; however, in some cases, a careful search may still not reveal their presence. Acid-fast staining of an impression smear made from the ileum of a cow with typical pathology is a quick, low-cost (albeit insensitive) method to arrive at a preliminary diagnosis. Biopsy of full-thickness sections of ileum and regional lymph nodes for culture and histopathology may provide a definitive diagnosis; however, this approach is usually restricted to particularly valuable animals. MAP has been isolated from a wide variety of tissue sites, but the mesenteric and ileocecal lymph nodes, ileum and liver are most frequently recommended for diagnostic sampling. A MAP could be detected in formalin fixed, paraffin embedded tissue samples by Immuno-histochemistry (IHC) and in situ hybridization (ISH). IHC and ISH were useful for the postmortem diagnosis of paratuberculosis although further work with a larger number of samples is required to examine sensitivity, specificity and possible alternate protocols for both techniques.

\section{Cell mediated immune response assay}

During the course of infection, cattle develop cell mediated immune (CMI) response to protect itself against the intracellular MAP infection. Delayed-type hypersensitivity (DTH) is detectable early in the infection and remains present in a proportion of the sub clinically infected carriers. The test works by developing a DTH response upon injection of Johnin purified protein derivative (Johnin PPD). However, the animal might also get sensitized by the exposure of environmental saprophytic Mycobacterium which results in nonspecific DTH reactions. Since the Johnin PPD is an undefined mix of antigens, paratuberculosis vaccinated animals might also cross reacts with Johnin PPD.
Lymphocyte transformation test and IFN- $\gamma$ assay are also based on CMI and they are used more on research basis. In the early and subclinical stages of infection, the symptoms are in apparent and hence, understanding the CMI response is essential for an early diagnosis of MAP. It is possible to exploit the presence of CMI mediators such as IFN- $\gamma$, a cytokine secreted by T-helper cells (Type 1) for the early diagnosis of the disease. Research suggests early MAP specific CMI responses can be measured using the IFN- $\gamma$ test [45]. However, the available whole blood IFN- $\gamma$ tests for MAP diagnosis also use PPD $j$ and therefore, carry the same specificity related problems similar to DTH. To augment the specificity of the IFN- $\gamma$ test, well defined and MAP specific antigens may be included in the whole blood stimulation. Few antigens have already been tested to understand the recall CMI responses against MAP [10]. The different types of antigens so far tested include secreted antigens [46], cell wall and membrane antigens [47], lipoproteins [48], heat shock proteins [49], HSP-65 and $35 \mathrm{kDa}$ proteins and various other hypothetical proteins. The optimal combination of novel antigens to be included in a MAP specific IFN- $\gamma$ test remains to be elusive. Studies have been performed to attain diagnosis of paratuberculosis in young animals by the detection of IFN- $\gamma[50,51]$. However, these results indicated that the use of IFN- $\gamma$ EIA in young animals had been flawed by the non-specific reactions and uncertain interpretation of the assays. The genome of MAP has recently been described and may provide the basis for new diagnostic approaches.

Early stage of MAP infection can be detected by measuring specific CMI responses by IFN- $\gamma$ release assay [45]. Currently the IFN- $\gamma$ test for MAP diagnosis is a sensitive tool, but the assay uses the PPDj, which is the crude undefined protein extract of MAP culture. Moreover, lack of standardized PPDj preparation method creates variation in antigen composition between laboratories. PPDj are known to cross-react with environmental mycobacteria such as MAA leading to low specificity of the IFN- $\gamma$ test. Furthermore, identifying the IFN inducing antigens of MAP would be useful not only for improving the CMI-based diagnostic test, but also for gaining a better understanding of the host immune responses against this organism, because IFN- $\gamma$ is considered to be one of the essential cytokines that play a number of important roles in achieving a protective immune response. To increase the specificity of the IFN- $\gamma$ test, ESAT- 6 family proteins [52], latency proteins [53], secreted proteins [54], proteins not present in MAA and a protein from an immunological hot spot region were evaluated. The optimal combination of novel antigens to be included in a MAP specific IFN- $\gamma$ test remains to be identified. MAP specific PPE proteins, HSP 65 and $35 \mathrm{Kda}$ were expressed on the cell surface and have been found to be immunodominant antigens. They are reported to be potent T-cell and B-cell antigens [55] and responsible for antigenic variation [56]. The name PPE is derived from the motifs Pro-Pro-Glu, found in conserved domains near the $\mathrm{N}$ termini of these proteins having 180 amino acid sequences in Mycobacterial species [57]. The PPE family of proteins such as MAP 10, MAP 39, MAP 1518, MAP 3185 and MAP41 was found to be potent IFN- $\gamma$ inducing antigens recognized by the experimental MAP infected animal in the early stages. CMI target antigens for early MAP detection are presented in Table 4.

\section{Detection of humoral immune response}

Though the early response of MAP infected is CMI, the response decreases in clinical cases. The serum antibody response becomes predominant in the clinical disease. Some traces of serum antibodies 
Citation: Maroudam V, Mohana Subramanian B, Praveen Kumar P, Dhinakar Raj G (2015) Paratuberculosis: Diagnostic Methods and their Constraints . J Veterinar Sci Technol 6: 259. doi:10.4172/2157-7579.1000259

Page 5 of 9

may also be present in carriers that have recovered from infection. The serum antibody titers are more constant and are at higher levels as lesions become more extensive. Serologic tests are rapid and low-cost method for antemortem confirmation of the disease; sensitivity is $>85 \%$ in clinically affected animals. The serological tests are also useful to detect the infection in clinically normal cattle which are shedding large numbers of MAP. In the serologic tests, those based on ELISA technology offer the highest sensitivity and specificity, and are best used to determine the prevalence of infection in a herd. A list of commercial ELISA kits was listed in the Table 5. Complement fixation (CF) test is also used as serological test. The CF test is still required by many countries for importation of animals, although many of the reagents used in the CF test are made to follow different specifications in different countries, resulting in a lack of standardization.

\begin{tabular}{|c|c|c|}
\hline Antigen & Remarks & Reference \\
\hline Johnin PPD or PPDj & $\begin{array}{l}\text { Low specificity to diagnose } \\
\text { MAP over non-MAP mycobacterial exposure }\end{array}$ & [71] \\
\hline PPE family proteins (Map 41 and Map39) & $\begin{array}{l}\text { PPE proteins have high specificity to MAP. PPE do not cross-react with } M \text {. avium subsp. } \\
\text { avium, }\end{array}$ & [47] \\
\hline PPE proteins of MAP & Elicits $T$ cell based IFN-y immunity in mice. & [72] \\
\hline $\begin{array}{l}\text { Mycobacterial heat-shock protein of } 70 \mathrm{kD}_{\mathrm{a}} \\
\text { (HSP70) }\end{array}$ & $\begin{array}{l}\text { HSP } 70 \text { is well-defined antigen in comparison with PPD antigens and can be used to } \\
\text { monitor CMI responses }\end{array}$ & [73] \\
\hline Recombinant HSP-65 and 35kda & Early detection of CMI in the MAP infected calve & [74] \\
\hline L5P, Para-LP-01 and PstA & Reported to be absent in MAA, but their diagnostic values remain to be validated & {$[75,76]$} \\
\hline Fusion protein ESAT-6 : CFP-10 & $\begin{array}{l}\text { Fusion protein differentiation of tuberculosis from MAP. Fusion protein is specific for } \\
\text { tuberculosis }\end{array}$ & {$[77]$} \\
\hline
\end{tabular}

Table 4: Diagnostic assay using MAP specific antigens.

\begin{tabular}{|l|l|l|l|}
\hline ELISA method & Antigen coated & Company name & Country \\
\hline Indirect ELISA & Liporabinomannan & Svanovir Para-TB Ab & Uppsala, Sweden \\
\hline Indirect ELISA & MAP extract & ID Screen Paratuberculosis Indirect,IDVET & Montpellier, France \\
\hline Indirect ELISA & Protoplasmic MAP antigens & Institut Pourquier & With pre-absorption \\
\hline Indirect ELISA & Protoplasmic MAP antigens & Allied Monitor & Missouri, USA \\
\hline
\end{tabular}

Table 5: List of commercial kits available for serodiagnosis of MAP.

\section{Genome detection of MAP}

An animal showing clinical signs of the disease is more likely to provide diagnostic evidence of the infection (shedding, antibody production) than an animal at the preclinical stage of infection. Use of various tests in combination can increase diagnostic sensitivity. Given the biology of the infection and the need to manage it on a herd basis, diagnostic information should be gathered for a group of animals rather than for an individual case. Feces and milk are very important source of infection and sustaining of MAP. Thus, detection of MAP in these samples was attempted by various researchers and detection of MAP shedding has become a major diagnostic tool. Major MAP gene targets and their detection limits are presented in Table 6.

\begin{tabular}{|c|c|c|c|c|}
\hline Gene targeting & Types of molecular techniques & Source of samples & Detection limit & Reference \\
\hline IS900 & PCR & Feces & 7.6x106MAP/g & [78] \\
\hline IS900 & PCR & Lymph nodes & 4.4x107MAP/g & [78] \\
\hline P89,P92 & In situ PCR & Tissue & & [79] \\
\hline F57 & Real time PCR & Infant milk powder & 10,000cells/g & {$[80]$} \\
\hline IS900, F57 & PCR & Culture & $1 \mathrm{cfu} / \mathrm{pcr}$ & [81] \\
\hline IS900 & PCR & Milk & 0.21 & [82] \\
\hline IS900 & PCR & Culture & 1 organism & [82] \\
\hline
\end{tabular}




\begin{tabular}{|l|l|l|l|l|}
\hline IS900 & PCR & Milk & $10-100 \mathrm{cfu} / \mathrm{ml}$ & {$[83]$} \\
\hline ISMAP02 & Triplex PCR & Feces & $10 \mathrm{MAP}$ cells/gm & {$[84]$} \\
\hline
\end{tabular}

Table 6: List of gene targets used in molecular assays and their detection limits.

\section{Challenges and Limitation of MAP Diagnostic Tests}

\section{Diagnostic sensitivity and specificity problems}

For paratuberculosis diagnosis, there is no reference standard and in reality, few true reference standards exist or otherwise they require that the animal is dead. Sensitivity and specificity for MAP diagnostics test vary significantly with different infection stages.

\section{Sample and its stage of infection}

Different diagnostic tests can be used at different stages of MAP infection. The stage of MAP infection is related to the age of animals, and calve are thought to be most susceptible to infection [58]. Figure 1 outline the various stages of MAP infection, which is related to the age of animals, transmission of MAP bacteria and how the diagnostic tests ELISA, culture and IFN- $\gamma$ perform at these infection stages.

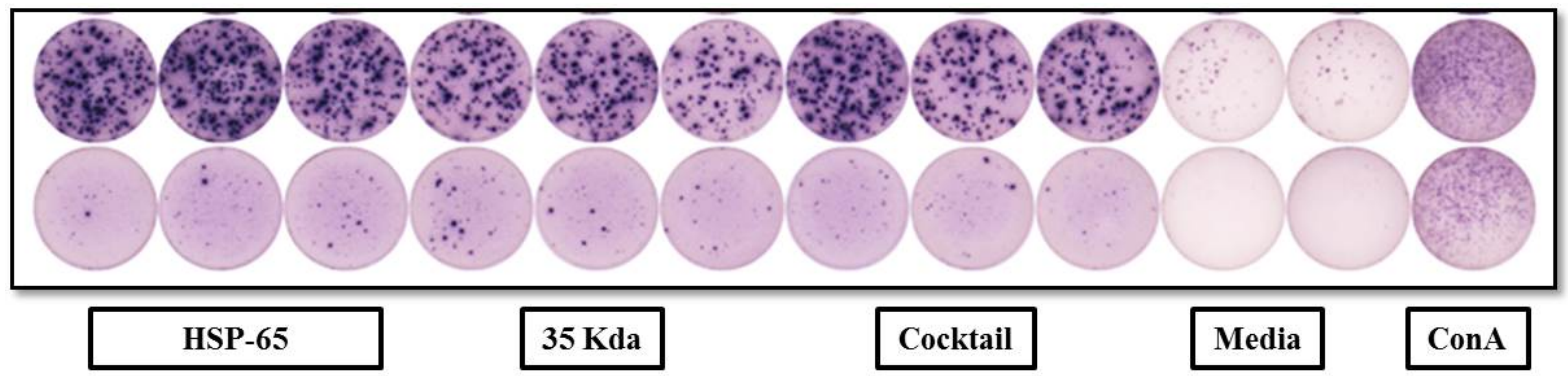

Figure 1: ELISPOT Results of HSP65 and 35Kda recombinant proteins (First row of wells was seeded with PBMCs from JD infected animal and the second row of wells was seeded with PBMCs from naïve animals).

\section{IFN-gamma release assay and its limitations in blood sampling}

IFN- $\gamma$ release assay from whole blood is used for the diagnosis of bovine tuberculosis and paratuberculosis [45]. However, the blood culture should be initiated within eight to twelve hours of blood sampling to ensure viability of IFN- $\gamma$ producing $\mathrm{T}$ cells. Under field conditions, this time limitation of sample collection from farm to laboratory testing is a problem and this limits the utility of the IFN- $\gamma$ test. A protocol with day-old blood samples and co-culture with recombinant bovine IL-12 has been developed as an alternative to the conventional IFN- $\gamma$ protocol using fresh blood samples. In this modified protocol, start of culture with antigens should be initiated within $20 \mathrm{hrs}$ of sample collection. However, a sophisticated lab is required, which is not possible in developing and underdeveloped nations [59].

\section{Neopterin}

Neopterin is synthesized in vitro by monocyte derived macrophages and dendritic cells in response to stimulation with IFN- $\gamma$ and is considered an excellent marker of cellular immune activation. IFN- $\gamma$ was until recently considered to be the only cytokine that could induce significant production of neopterin, but in vitro experiments suggested that also interferon alpha (IFN- $\alpha$ ) and interferon beta (IFN- $\beta$ ) can induce neopterin synthesis of dendritic cells [60]. Detection of neopterin instead of direct measurement of IFN- $\gamma$ has various advantages, since IFN $-\gamma$ is subject to fast degradation and is able to bind to soluble or cell bound receptors, the measured IFN- $\gamma$ may not represent the actual freely available IFN- $\gamma$ level. Neopterin is biochemically inert and stable because its half-life in the human body is solely due to renal excretion. Furthermore, neopterin is synthesized one step further down the activation pathway -eliminating the noise from unspecific IFN- $\gamma$ production by NK cells. High neopterin levels are observed in different inflammatory disease and certain malignancies and can be measured in serum and urine [61]. Routine neopterin screening is commonly used in human medicine. As an example, Austrian blood donations have been screened since 1994, and those with elevated levels are excluded from transfusion [62]. The use of neopterin assays in veterinary medicine is limited and has so far only been approached by very few authors. They have measured neopterin in cattle, pigs, llamas, dogs, cats, rabbit and rats [63]. Neopterin is measured by High Performance Liquid Chromatography (HPLC), Radio Immuno Assay (RIA) and by competitive ELISA.

\section{Control and Prevention}

MAP is usually resistant to chemotherapeutic agents in vitro and treatment of infected animals has not been successful. The OIE recommended kits (Table 7) on MAP control aretested and culling of the MAP positive animals. However, it will be challenging to implement the culling policy in developing countries due to socioeconomic reasons. Thus the effective disease control programs depend on a clear understanding of the sources of infection and the routes of transmission and early detection of infected animals, thereby allowing the removal of carrier individuals from the herd. Vaccination reduces the incidence of clinical disease in ruminants and to reduce or delay the fecal excretion of bacterial load [64]. The Current JD vaccines raised conflicting data on local tissue reactions/cross reactions, reduction in shedding limits and their usefulness for control programs 
Page 7 of 9

[65]. The available vaccines could not elicit $100 \%$ protective immune response which could give sterile immunity [66]. Few commercially available MAP vaccines are i) MAP Strain 18 oil emulsion, USA; ii) Weybridge Vaccine, UK; iii) Gudair MAP Strain 318F oil emulsion, Pfizer CSL; iv) Aqua VAX Map strain 316F Water based and v) Neoparasec Freeze Dried Live MAP, Merial. The desired characteristics of an ideal future MAP vaccine are the ability to differentiate the infected animals from the TB and MAP vaccinated animals and absence of injury at the site of injection. Routine vaccination of cattle against paratuberculosis is not recommended as it could interfere with both humoral and CMI based diagnostics involved in the control programs [3].

\begin{tabular}{|c|c|c|c|c|}
\hline Diagnostic test & Advantage & Sensitivity & Specificity & Limitation \\
\hline $\begin{array}{l}\text { Antibody detection (serum } \\
\text { ELISA) }\end{array}$ & Rapid and economical & $15-85 \%$ & $97-100 \%$ & \multirow{2}{*}{$\begin{array}{l}\text { Can be detected only in the later stages of disease by the time } \\
\text { the entire environment could have been contaminated }\end{array}$} \\
\hline $\begin{array}{l}\text { Antibody detection (Milk } \\
\text { ELISA) }\end{array}$ & Rapid and economical & $21-64 \%$ & $80-99 \%$ & \\
\hline $\begin{array}{l}\text { Organism detection (Fecal } \\
\text { Culture) }\end{array}$ & Slow and expensive & $50 \%$ & $95 \%$ & Low sensitivity \\
\hline IFN-y assay & $\begin{array}{l}\text { Rapid and sensitive; early } \\
\text { diagnosis }\end{array}$ & - & - & Low specificity \\
\hline
\end{tabular}

Table 7: The nutshell of all important diagnostic techniques.

The disease can be controlled by implementing good hygienic practices. It can also be controlled by preventing the animals (especially newborns) from contacting/ingest the bacteria from the infected animals. In case of in-utero infection, culling the pregnant animal serves as a better prevention method. Manure, colostrum, milk, feed and water management under good hygienic conditions is one of the prerequisites for prevention of the disease [67-69]. Avoiding unplanned introduction of animals from herds of unknown disease status, preventing grazing in land used by other herds or susceptible species and screening the animals before introducing an animal into the herd are some of the other disease prevention measures.

\section{Conclusion}

Paratuberculosis continues to be a challenge for cattle producers and veterinarians. Effective disease control programs depend on early diagnosis of infection and management of sources of infection and the routes of transmission. Early response in paratuberculosis is CMI response and the response can be detected by IFN- $\gamma$ assays. However, the IFN- $\gamma$ response against purified protein derivative (PPD) seems to be less specific. Diagnosis of the MAP is a challenge due to the chronic nature and the presence of four stages of disease via, stage I, 'silent' infection; stage II, in apparent carrier animals; stage III, clinical disease; stage IV, advanced clinical disease. Thus, a battery of tests is required to detect a JD infected animal in a farm. The specificity of the assay can be improved using a cocktail of MTB specific recombinant antigens. The progression of MAP infection to different stages of disease varies and will depend on the immune status of individual animals. Thus, no single diagnostic test can be applied to detect MAP infection of various stages (Table 7). Veterinarians should educate farm/animal owners about paratuberculosis and its management practices. Segregation of newborn calves from the calving environment and from sources of fecal contamination will lower the incidence of paratuberculosis. Still a predicament exits in the zoonotic role of MAP and also on its transmissible pattern to humans. Therefore, control of paratuberculosis infection in farm animals should be considered as a priority.

\section{Conflict of Interest Statement}

We declare that we have no conflict of interest.

\section{References}

1. Roupie V, Viart S, Leroy B, Romano M, Trinchero N, et al. (2012) Immunogenicity of eight Mycobacterium avium subsp. paratuberculosis specific antigens in DNA vaccinated and Map infected mice. Vet Immunol and Immunopathol 15: 74-85.

2. Ott SL, Wells SJ, Wagner BA (1999) Herd-level economic losses associated with Johne's disease on US dairy operations. Prev Vet Med 40: 179-192.

3. Collins MT (1994) Clinical approach to control of bovine paratuberculosis. J Am Vet Med Assoc 204: 208-210.

4. Rosenberger AE, Whitlock RH, Siebert M, Sweeney RW (1992) Environmental survey for Mycobacterium paratuberculosis on dairy farms with a history of Johne's disease. In: Chiodini RJ, Kreeger JM, (Eds) Proceedings of the Third International Colloquium on Paratuberculosis. Providence: International Association for Paratuberculosis.

5. Clarke CJ (1997) The pathology and pathogenesis of paratuberculosis in ruminants and other species. J Comp Pathol 116: 217-261.

6. Stehman SM (1996) Paratuberculosis in small ruminants, deer, and South American camelids. Vet Clin North Am Food Anim Pract 12: 441-455.

7. Taylor TK, Wilks CR, McQueen DS (1981) Isolation of Mycobacterium paratuberculosis from the milk of a cow with Johne's disease. Vet Rec 109: 532-533.

8. Economou M, Pappas G (2008) New global map of Crohn's disease: Genetic, environmental, and socioeconomic correlations. Inflamm Bowel Dis 14: 709-720.

9. OIE (2007) Bovine tuberculosis. Manual of diagnostic tests and vaccines for terrestrial animals. World Organization for Animal Health, Paris, France.

10. Mikkelsen H, Aagaard C, Nielsen SS, Jungersen G (2011) Review of Mycobacterium avium subsp. paratuberculosis antigen candidates with diagnostic potential. Vet Microbiol 152: 1-20.

11. Fecteau ME, Whitlock RH (2009) Paratuberculosis in cattle. In Behr MA, Collins DM (Eds) Paratuberculosis. Organism, Disease, Control, CAB International, UK.

12. Stevenson K (2015) Genetic diversity of Mycobacterium avium subspecies paratuberculosis and the influence of strain type on infection and pathogenesis: a review. Vet Res 46: 64 . 
13. Körmendy B, Kopál T, Bálint T, Szilágyi M, Béki L (1989) Economic losses caused by paratuberculosis in a dairy herd: case report. Acta Vet Hung 37: 45-53.

14. Nordlund KV, Goodger WJ, Pelletier J, Collins MT (1996) Associations between subclinical paratuberculosis and milk production, milk components, and somatic cell counts in dairy herds. J Amer Vet Med Assoc 208: 1872-1876.

15. Johnson-Ifearulundu Y, Kaneene JB (1997) Epidemiology and economic impact of subclinical Johne's disease: a review. Vet Bull 67: 437-447.

16. Riemann HP, Abbas B (1983) Diagnosis and control of bovine paratuberculosis (Johne's disease). Adv Vet Sci Comp Med 27: 481-506.

17. Jones RL (1989) Review of the economic impact of Johne's disease in the US. In: Johne's disease, Current Trends in Research Diagnosis and Management. Victoria, Australia, CSIRO.

18. Wells SJ, Wagner BA (2000) Herd-level risk factors for infection with Mycobacterium paratuberculosis in US dairies and association between familiarity of the herd manager with the disease or prior diagnosis of the disease in that herd and use of preventive measures. J Am Vet Med Assoc 216: 1450-1457.

19. Smith RL, Grohn YT, Pradhan AK, Whitlock RH, Van Kessel JS, et al. (2009) A longitudinal study on the impact of Johne's disease status on milk production in individual cows. J Dairy Sci 92: 2653-2661.

20. Aly S, Wagner K, Keller C, Malm S, Malzan A, et al. (2006) Oxygen status of lung granulomas in Mycobacterium tuberculosis-infected mice. J Pathol 210: 298-305.

21. Crohn BB, Ginzburg I, Oppenheimer GD (1932) Regional ileitis: a pathologic and clinical entity. J America Med Assoc 99: 1323 -1328.

22. Zhou R, Tardivel A, Thorens B, Choi I, Tschopp J (2010) Thioredoxininteracting protein links oxidative stress to inflammasome activation. Nat Immunol 11: 136-140.

23. Chiodini RJ, Van Kruiningen HJ, Merkal RS (1984) Ruminant paratuberculosis (Johne's disease): the current status and future prospects. Cornell Vet 74: 218-262.

24. Chiodini RJ (1989) Crohn's disease and the mycobacterioses: a review and comparison of two disease entities. Clin Microbiol Rev 2: 90-117.

25. Greenstein RJ (2003) Is Crohn's disease caused by a mycobacterium? Comparisons with leprosy, tuberculosis, and Johne's disease. Lancet Infect Dis 3: 507-514.

26. Juste RA, Portu J, Aldamiz M, Ocariz CS, Chiodini R (2007) Seroreactivity of Crohn's disease patients to mycobacterial antigens: original data and analytical review of the literature. Animal Vet (Murcia) 23: 91-103.

27. Mihajlovic B, Farber MH, Couture J, Gleeson T, Lim H (2007) Evaluation of Current Evidence for Human Exposure to Mycobacterium avium subsp. paratuberculosis (MAP) and its Association with Crohn's Disease (CD), Health Canada Science Forum.

28. Grant IR (2005) Zoonotic potential of Mycobacterium avium ssp. paratuberculosis. the current position. J Appl Microbiol 98: 1282-1293.

29. Whan LB, Grant IR, Ball HJ, Scott R, Rowe MT (2001) Bactericidal effect of chlorine on Mycobacterium paratuberculosis in drinking water. Lett Appl Microbiol 33: 227-231.

30. Le Dantec C, Duguet JP, Montiel A, Dumoutier N, Dubrou S, et al. (2002) Occurrence of mycobacteria in water treatment lines and in water distribution systems. Appl Environ Microbiol 68: 5318-5325.

31. Sibartie S, Scully P, Keohane J, O'Neill S, O'Mahony J, et al. (2010) Mycobacterium avium subsp. Paratuberculosis (MAP) as a modifying factor in Crohn's disease. Inflamm Bowel Dis 16: 296-304.

32. Simmons DP, Canaday DH, Liu Y, Li Q, Huang A, et al. (2010) Mycobacterium tuberculosis and TLR2 agonists inhibit induction of type I IFN and class I MHC antigen cross processing by TLR9. J Immunol 185 2405-2415.

33. Eltholth MM, Marsh VR, Van Winden S, Guitian FJ (2009) Contamination of food products with Mycobacterium avium paratuberculosis. a systematic review. J Appl Microbiol 107: 1061-1071.
34. Sweeney RW (1996) Transmission of paratuberculosis. Vet Clin North Am Food Anim Pract 12: 305-312.

35. Amstutz HE (1984) Bovine paratuberculosis. an update. Mod Vet Pract 65: 134-135.

36. Larsen AB, Miller JM (1978) Mammary gland exposure of cows to Mycobacterium paratuberculosis. Am J Vet Res 39: 1972-1974.

37. Ayele WY, Machackova M, Pavlik I (2001) The trans $\neg$ mission and impact of paratuberculosis infection in domestic and wild ruminants. Vet MedChecz 46: 205-224.

38. Doyle TM (1954) Isolation of Johne's bacilli from the udders of clinically affected cows. Bri Vet J 110: 215 -218.

39. Merkal RS, Larsen AB, Booth GD (1975) Analysis of the effect of inapparent bovine paratuberculosis. Am J Vet Res 36: 837-838.

40. Buergelt CD, Duncan JR (1978) Age and milk production data of cattle culled from a dairy herd with paratuberculosis. J Am Vet Med Assoc 173: 478-480.

41. Cocito C, Gilot P, Coene M, de Kesel M, Poupart P, et al. (1994) Paratuberculosis. Clin Microbiol Rev 7: 328-345.

42. OIE (2008) Bovine tuberculosis. In: Manual of Diagnostic Tests and Vaccines for Terrestrial Animals (mammals, birds and bees).

43. Whitlock RH, Buergelt C (1996) Preclinical and clinical manifestations of paratuberculosis (including pathology). Vet Clin North Am Food Anim Pract 12: 345-356.

44. Whipple DL, Callihan DR, Jarnagin JL (1991) Cultivation of Mycobacterium paratuberculosis from bovine fecal specimens and a suggested standardized procedure. J Vet Diagn Invest 3: 368-373.

45. Wood PR, Kopsidas K, Milner AR, Hill J, Gill I et al. (1989) The development of an in vitro cellular assay for Johne's disease in cattle. In: Milner AR, Wood PR edn. Johne's Disease. Current Trends in Research, Diagnosis and Management. CSRIO Publications, Melbourne, Australia.

46. Olsen JE (1985) On the reduction of Mycobacterium paratuberculosis in bovine slurry subjected to batch mesophilic or thermophilic anaerobic digestion. Agri Waste 13: 273-280.

47. Nagata R, Muneta Y, Yoshihara K, Yokomizo Y, Mori Y (2005) Expression cloning of gamma interferon-inducing antigens of Mycobacterium avium subsp. paratuberculosis. Infect Immun 73: 3778-3782.

48. Huntley JF, Stabel JR, Bannantine JP (2005) Immunoreactivity of the Mycobacterium avium subsp. paratuberculosis 19-kDa lipoprotein. BMC Microbiol 5: 3 .

49. Koets AP, Rutten VP, Hoek A, Bakker D, van Zijderveld F, et al. (1999) Heat-shock protein-specific T-cell responses in various stages of bovine paratuberculosis. Vet Immunol Immunopathol 70: 105-115.

50. Collins MT, Zhao BY (1995) Comparison of the commercial serum antibody ELISA, interferon-? test kit, and radiometric faecal culture for early diagnosis of paratuberculosis in experimentally infected Holstein calves. In: Chiodini RJ, Collins MT, Bassey EOE, (eds.): Proc. 4th International Colloquium on Paratuberculosis. Int. Assoc. for Paratuberculosis Inc., Rehoboth, MA, USA.

51. McDonald WL, Ridge SE, Hope AF, Condron RJ (1999) Evaluation of diagnostic tests for Johne's disease in young cattle. Aust Vet J 77: 113-119.

52. van Pinxteren LA, Ravn P, Agger EM, Pollock J, Andersen P (2000) Diagnosis of tuberculosis based on the two specific antigens ESAT-6 and CFP10. Clin Diagn Lab Immunol 7: 155-160.

53. Leyten EM, Lin MY, Franken KL, Friggen AH, Prins C, et al. (2006) Human T-cell responses to 25 novel antigens encoded by genes of the dormancy regulon of Mycobacterium tuberculosis. Microbes Infect 8: 2052-2060.

54. Cho D, Collins MT (2006) Comparison of the proteosomes and antigenicities of secreted and cellular proteins produced by Mycobacterium paratuberculosis. Clin Vaccine Immunol 13: 1155-1161.

55. Choudhary RK, Mukhopadhyay S, Chakhaiyar P, Sharma N, Murthy KJR (2003) PPE antigen Rv2430c of Mycobacterium tuberculosis induces a strong B-cell response. Infect Immunol 71: 6338-6343. 
56. Cole ST, Brosch R, Parkhill J, Garnier T, Churcher C, et al. (1998) Deciphering the biology of Mycobacterium tuberculosis from the complete genome sequence. Nat 393: 537-544.

57. Okkels L, Brock I, Follmann F, Agger EM, Arend SM, et al. (2003) PPE protein (Rv3873) from DNA segment RD1 of Mycobacterium tuberculosis: strong recognition of both specific T-cell epitopes and epitopes conserved within the PPE family. Infect Immunol 71: 6116-6123.

58. Doyle TM (1958) Fetal infection in Johne's disease.Vet Rec 70: 328.

59. Maroudam Veerasami, Loganthan Moorthy, Dipankar Das, SugumarParthasarthy, DevChandran et al. (2011) Assessment of critical parameters in blood processing for the bovine interferon-gamma ELISPOT assay to detect Mycobacterium bovis infected cattle in India. Vet Ita 47: 25-34.

60. Wirleitner B, Reider D, Ebner S, Böck G, Widner B, et al. (2002) Monocyte-derived dendritic cells release neopterin. J Leukoc Biol 72: 1148-1153.

61. Hamerlinck FF, Klatser PR, Walsh DS, Bos JD, Walsh GP, et al. (1999) Serum neopterin as a marker for reactional states in leprosy. FEMS Immunol Med Microbiol 24: 405-409.

62. Renneberg R, Chan CP, Nie YM, Leung MF, Bergmann A, et al. (2006) Neopterin screening to improve safety of blood transfusion. Pter 17: 103-104.

63. Breineková K, Svoboda M, Smutná M, Vorlová L (2007) Markers of acute stress in pigs. Physiol Res 56: 323-329.

64. van Schaik G, Kalis CH, Benedictus G, Dijkhuizen AA, Huirne RB (1996) Cost-benefit analysis of vaccination against paratuberculosis in dairy cattle. Vet Rec 139: 624-627.

65. Rideout BA, Brown ST, Davis WC, Gay JM, Giannella RA, et al. (2003) The diagnosis and control of Johne's Disease: Committee on the diagnosis and control of johne's disease. National Academy of Sciences. National Academy Press, Washington DC.

66. Flynn JL, Chan J (2001) Immunology of tuberculosis. Annu Rev Immunol 19: 93-129.

67. Greig A, Stevenson K, Henderson D, Perez V, Hughes V, et al. (1999) Epidemiological study of paratuberculosis in wild rabbits in Scotland. J Clin Microbiol 37: 1746-1751.

68. St-Jean G1, Jernigan AD (1991) Treatment of Mycobacterium paratuberculosis infection in ruminants. Vet Clin North Am Food Anim Pract 7: 793-804.

69. Pavlik I, Bartl J, Dvorska L, Svastova P, Du Maine R, et al. (2000a) Epidemiology of paratuberculosis in wild ruminants studied by restriction fragment length polymorphism in the Czech Republic during the period 1995-1998. Vet Microbiol 77: 231-251.

70. Stevenson K (2010) Diagnosis of Johne's disease: current limitations and prospects. Cattle Pract18: 104-109.

71. McDonald WL, Ridge SE, Hope AF, Condron RJ (1999) Evaluation of diagnostic tests for Johne's disease in young cattle. Aust Vet J 77: 113-119.

72. Rajib Deb, Goswami PP (2011) Coexpression of PPE 34.9 Antigen of Mycobacterium avium subsp. Paratuberculosis with Murine Interferon
Gamma in HeLa Cell Line and Study of Their Immunogenicity in Murine Model. Biotechnol Res Int 1-10.

73. Fernández-Silva JA1, Abdulmawjood A, Bülte M (2011) Diagnosis and Molecular Characterization of Mycobacterium avium subsp. paratuberculosis from Dairy Cows in Colombia. Vet Med Int 2011: 352561.

74. GangadharraoApana, Dipankar Das, Maroudam Veerasami, Ramachandran Lakshmikanthan, Senthilkumar, et al. (2013) Antemortem and post-mortem examinations of the cattle calf naturally infected with Mycobacterium avium subsp. Paratuberculosis. Eur J Microbiol and Immunol 4: 241-251.

75. Eckstein TM, Chandrasekaran S, Mahapatra S, McNeil MR, Chatterjee D, et al. (2006) A major cell wall lipopeptide of Mycobacterium avium subspecies paratuberculosis. J Biol Chem 281: 5209-5215.

76. Wu CW, Schmoller SK, Bannantine JP, Eckstein TM, Inamine JM, et al. (2009) A novel cell wall lipopeptide is important for biofilm formation and pathogenicity of Mycobacterium avium subspecies paratuberculosis. Microb Pathog 46: 222-230.

77. Veerasami M, Moorthy L, Das D, Parthasarathy S, Chandran D, et al. (2011) Assessment of critical parameters in blood processing for the bovine interferon-gamma ELISPOT assay to detect Mycobacterium bovis infected cattle in India. Vet Ital 47: 25-34.

78. Münster P, Völkel I, von Buchholz A, Czerny CP (2013) Detection of Mycobacterium avium subspecies paratuberculosis by IS900-based PCR assays from an alpaca (Vicugna pacos) kept in a German zoological garden. J Zoo Wildl Med 44: 176-180.

79. Delgado F, Aguilar D, Garbaccio S, Francinelli G, Hernández-Pando R, et al. (2011) Detection of Mycobacterium avium subsp. paratuberculosis by a Direct In Situ PCR Method. Vet Med Int 2011: 267102.

80. Hruska K, Slana I, Kralik P, Pavlik I (2011) Mycobacteriuma avium sub sp. paratuberculosis in powdered infant milk: F57 competitive real time PCR. Vet Med 56: 226-230.

81. Vansnick E, De Rijk P, Vercammen F, Geysen D, Rigouts L, et al. (2004) Newly developed primers for the detection of Mycobacterium avium subspecies paratuberculosis. Vet Microbiol 100: 197-204.

82. Jayarao BM, Pillai SR, Wolfgang DR, Griswold DR, Rossiter CA, et al. (2004) Evaluation of IS900-PCR assay for detection of Mycobacterium avium subspecies paratuberculosis infection in cattle using quarter milk and bulk tank milk samples. Foodborne Path and Dis 1:17-26.

83. Pillai SR, Jayarao BM (2002) Application of IS900 PCR for detection of Mycobacterium avium subsp. paratuberculosis directly from raw milk. J Dairy Sci 85: 1052-1057.

84. Sevilla IA, Garrido J, Molina E, Geijo MV, Elguezabal N, et al. (2014) Development and evaluation of a novel multicopy-element-targeting triplex PCR for detection of Mycobacterium avium subsp. paratuberculosis in feces. Appl Environ Microbiol 80: 3757-3768. 